\author{
Катерина Гнатовська, \\ аспірантка кафедри початкової і професійної освіти, \\ Харківський національний педагогічний університет \\ імені Г.С. Сковороди \\ (м. Харків, Україна)

\section{Kateryna Hnatovska,} \\ Graduate student of the Department of Primary and \\ Professional Education \\ H.S. Skovoroda Kharkiv National Pedagogical University \\ (Kharkiv, Ukraine) \\ ka.hnatovska@gmail.com \\ ORCID ID 0000-0002-0991-7507
}

удк: 378.015.31-044352:130.2

\title{
КУЛЬТУРОЛОГІЧНИЙ ПІДХІД ЯК ЗАСІБ ФОРМУВАННЯ ТОЛЕРАНТНОСТІ МАЙУТНІХ ФАХІВЦІВ
}

\begin{abstract}
Анотація. Стаття присвячена вивченню проблем толерантності та культурологічному підходу як засобу формування толерантності майбутніх спеціалістів. Толерантність визначено як особистісно значущу якість особистості. Зміст толерантних якостей визначається здатністю особистості до морально зумовленого вибору, спрямованістю рис її характеру, впливом навколишнього середовища, прихильністю до тих чи інших ідей. Проаналізовано значення культурологічного підходу з позиції формування толерантності молодого покоління. Описано, що поняття «толерантність» 3 огляду на його інтегративний характер $€$ предметом вивчення різних наук: філософії, етики, політології, соціології, психології, культурології, педагогіки тощо. З'ясовано, що у формуванні толерантності майбутніх фахівців чільне місце приділяється розвитку демократичного мислення, пошуку нових підходів до виховної діяльності, урахуванню історично-культурних традицій різних регіонів України. Визначено, що стратегія формування толерантності за допомогою культурологічного підходу полягає в тому, щоб забезпечити особистості всі необхідні умови для їі духовного розвитку, інтелектуально-моральної свободи, вибору поведінки, формування почуття громадянськості, патріотичної й національної самосвідомості, вільної світоглядної позиції, уміння відстоювати свої переконання щодо збереження миру на Землі, гуманного та толерантного ставлення до оточуючих. Мета статті - узагальнити підходи щодо визначень культурологічного підходу в контексті дослідження проблеми формування толерантності майбутніх фахівців. Відповідно до мети дослідження було визначено такі завдання: проаналізувати теоретичні основи понять «толерантність» та «культурологічний підхід»; розкрити сутність та особливості культурологічного підходу як засобу формування толерантності майбутніх фахівців. Для розв'язання поставлених завдань використано теоретичні методи аналізу й узагальнення наукової та методичної літератури з досліджуваної проблеми.
\end{abstract}

Ключові слова: толерантність, культурологічний підхід, цінності, виховання, формування, фахівці, засоби.

\section{CULTUROLOGICAL APPROACH AS A TOOL FOR DEVELOPMENT TOLERANCE IN FUTURE SPECIALISTS}

\footnotetext{
Abstract. The article is dedicated to the study of tolerance problems and culturological approach as a tool of development tolerance in future specialists. In this case, tolerance is defined as an individually significant quality of personality. The content of tolerance qualities is determined by an individual's ability to make a morally determined choice, orientation of his or her character traits, environmental influence, disposition towards certain ideas. The meaning of culturological approach from the point of view of development tolerance in young generation is being analyzed. It is noticed that the concept of 'tolerance', taking into account its integrative character, is a subject of study by different sciences, such as philosophy, ethics, political science, sociology, psychology, culturology, pedagogics, etc. It is established that a significant role in the formation of tolerance in future specialists is given to the development of democratic thinking, the search for new approaches to educational activities, taking into account historical and cultural traditions of different regions of Ukraine. It is defined that the strategy of tolerance formation with the help of culturological approach consists in providing a person with all necessary conditions for his or her spiritual development, intellectual and moral freedom, choice of behavior, formation of perception of citizenship, patriotic and national consciousness, free global outlook, ability to maintain the beliefs concerning preservation of peace on the Earth, compassionate and tolerant attitude to others.

The purpose of the article is to justify theoretical concepts of 'tolerance' and 'culturological approach' in scientific research and provide definitions of these concepts. According to the purpose of the research, the following tasks were defined: to analyze theoretical foundations of 'tolerance' and 'culturological approach' concepts; to determine the essence and peculiarities of culturological approach as a tool for development tolerance in future specialists.

Theoretical techniques for analysis and generalization of scientific and methodical literature on the problem under study were used to solve the tasks.
}

Keywords: tolerance, culturological approach, values, education, formation, specialists, tools. 


\section{ВСТУП}

Постановка проблеми. Сьогодні на етапі державного й духовного відродження України пріоритетна роль має належати розвитку національної системи освіти, здатної забезпечити рух суспільства на демократичних гуманних засадах шляхом прогресу, формування толерантності, забезпечення розвитку творчих сил та громадянської активності. Основою реформування освіти України визначається принцип людиноцентризму, забезпечення особистісного розвитку згідно з індивідуальними здібностями й потребами на основі навчання протягом життя. Національна система освіти та її складник - національне виховання - мають формуватися адекватно до сучасних інтеграційних і глобалізаційних процесів, вимогам переходу до постіндустріальної цивілізації, що забезпечить стійкий рух та розвиток України на сучасному етапі. Нові соціально-економічні умови становлення й розвитку нашої країни, інтеграція в європейське та світове товариство, завдання побудови демократичного суспільства об'єктивно зумовлюють потребу гуманістичної спрямованості навчально-виховного процесу, формування творчого потенціалу здобувачів освіти, оволодіння досягненнями української та світової культури. Організація освітнього процесу на основі демократичної, гуманістичної та гуманітарної спрямованості, органічне поєднання в його змісті національного та загальнолюдського начал, сприяють формуванню в майбутніх фахівців толерантності.

У формуванні толерантності сучасної молоді чільне місце приділяється розвитку демократичного мислення, пошуку нових підходів до виховної діяльності, урахуванню історично-культурних традицій різних регіонів України. Стратегія формування толерантності полягає в тому, щоб забезпечити особистості всі необхідні умови для її духовного розвитку, інтелектуально-моральної свободи, вибору поведінки, формування почуття громадянськості, патріотичної й національної самосвідомості, вільної світоглядної позиції, уміння відстоювати свої переконання щодо збереження миру на Землі, гуманного та толерантного ставлення до оточуючих. Людина завжди є частиною культури як системи цінностей, об'єктивно пов'язана з нею й не лише засвоює культурні надбання, a є їх творцем. Отже, засвоєння культури людиною і є її розвитком та становленням як творчої особистості. Тому саме культурологічний підхід в освіті забезпечує перехід досягнень культури суспільства в реалії повсякденного життя.

Аналіз наукових досліджень і публікацій. Вивченню толерантності присвятили свої дослідження зарубіжні й вітчизняні науковці. Зокрема, теоретичні аспекти формування толерантності у молодого покоління розглядали: А. Асмолова, Т. Атрощенко, В. Бабкіна, Т. Вінник, Н. Гасанова, В. Горбатенко, М. Євтух, В. Золотухіна, В. Лекторський, І. Оніщенко, та інші. Проблеми толерантності молоді досліджували С. Авраменко, О. Батуріна, Т. Білоус, Ю. Грачова, О. Грива, Я. Довгополова, І. Жданова, О. Зарівна, О. Рибак, О. Хижняк та інші. Педагогічний контекст феномена толерантності розглянуто у працях таких авторів, як І. Бех, М. Бубер, Л. Завірюха, В. Калошин, М. Карандаш, О. Матієнко, В. Рахматшаєва, В. Шалін та інші. Проблеми міжетнічної толерантності осмислюються в працях таких науковців, як: М. Баліашвілі, О. Грива, І. Данилюк, Л. Дробіжева, В. Євтух, Л. Залановська, І. Залєсова, М. Михайлова, Л. Орбан-Лембрик, М. Пірен, А. Погодіна, П. Дж. Роуз, Г. Солдатова, Л. Тогебі, М. Уолцер, М. Хараджи, Д. Хейд, Р. Шермерхорн та інші. Проблему полікультурної освіти, міжнаціональних відносин, виховання толерантності, емпатії, зокрема, в міжетнічних стосунках, досліджували А. Авксентьєв, Ю. Варфоломєєва, 3. Гасанов, О. Грива, О. Гуренко, Я. Довгополова, М. Євтух, В. Заслуженюк, Е. Койкова, В. Кузьменко, І. Кушніренко, В. Присакар, П. Саух, Т. Стефаненко, І. Тишик, В. Тугай, Ю. Яценко та інші Науковці, зокрема О. Березюк, Г. Назаренко, розкривають проблеми виховання міжетнічної толерантності на регіональному рівні, але вони стосуються загалом студентів майбутніх учителів і старшокласників.

Загальні питання реалізації культурологічного підходу в освітньому процесі, його системоутворювальна роль обговорюється у дослідженнях В. Андреєва, Ю. Бельчикова, Є. Бондаревської, А. Кирсанова, А. Ростовцева, В. Сластьоніна, Н. Щуркової та інших. Роль культурологічної підготовки як засобу формування професійного мислення, оволодіння повноцінними теоретичними знаннями та практичними вміннями аналізується в наукових студіях А. Арнольдова, Н. Багдасарян, Л. Буєвої, В. Родина, Е. Семенова, С. Тангяна та інших. Базові принципи побудови культурологічної дисципліни у закладах вищої освіти представлені в публікаціях А. Велика, И. Кефели, В. Межуєва, Ю. Рождественського, О. Флієра та інших. Значення культурологічних умінь в підвищенні комунікативної компетентності обговорюється в працях І. Зимньої, О. Карпова, Т. Китайгородської, А. Мудрика та інших.

\section{МЕТА І ЗАВДАННЯ ДОСЛІДЖЕННЯ}

Мета полягає в узагальненні підходів щодо визначень культурологічного підходу в контексті дослідження проблеми формування толерантності майбутніх фахівців. Відповідно до мети дослідження було визначено такі завдання: проаналізувати теоретичні основи понять «толерантність» та «культурологічний підхід»; розкрити сутність та особливості культурологічного підходу як засобу формування толерантності майбутніх фахівців.

\section{МЕТОДИ ДОСЛІДЖЕННЯ}

Для розв'язання поставлених завдань використано теоретичні методи аналізу й узагальнення наукової та методичної літератури з досліджуваної проблеми.

\section{РЕЗУЛЬТАТИ ДОСЛІДЖЕННЯ}

В українському менталитеті толерантність $€$ однією з найважливіших його характеристик. Сторіччями непростої, а часом трагічної історії, український народ накопичив дивне для іноземців власне терпіння, жертовного прийняття 
труднощів в ім'я збереження етнічної цілісності та державності. Сьогодні сприйняття або несприйняття молоддю інших національностей, толерантне ставлення до відмінностей між людьми, готовність поважати ці відмінності залежить від багатьох чинників, залучаючи: найближче оточення, цінності особистості й суспільства, виховання. Так само на сприйняття інших такими, якими вони є, впливає менталітет тієї країни, у якій людина виросла. Ми бачимо, що сучасна молодь схильна до розуміння відмінностей між людьми, бо толерантні установки закладені ще нашими предками. Молодь, на несвідомому рівні, здатна прийняти іншого таким, яким він є.

Науковець В. Лекторський зазначає, що толерантність - це єдність у різноманітті. Це не лише моральний обов'язок, а й політична та правова потреба. Толерантність - це не поступка, поблажливість чи потурання. Це, передусім, активна позиція, що формується на основі визнання універсальних прав та основних свобод людини (Лекторський В., 1997). Толерантність у жодному разі не може бути виправданням посягання на ці основні цінності. Виявлення толерантності не означає терпимого ставлення до соціальної несправедливості, відмови від своїх або прийняття чужих переконань. Це означає, що кожен може дотримуватись своїх переконань і визнає таке ж право за іншими. Це свідчить про визнання того, що люди за природою своєю відрізняються зовнішнім виглядом, становищем, мовою, поведінкою і мають право жити в мирі, в гармонії з собою і навколишнім світом та зберігати свою індивідуальність. Це також означає, що погляди однієї людини не можуть бути нав'язані іншим. Без толерантності не може бути миру, а без миру неможливі розвиток і демократія. Толерантність необхідна у взаєминах між окремими особами, у сім'ї та в громаді. У школах, університетах та осередках неформальної освіти, удома і на роботі, необхідно формувати атмосферу толерантності, душевності, відкритості, уважності один до одного та почуття солідарності. Усе це приходить через культуру виховання. Вихованню в дусі толерантності сприяє прищеплення почуття солідарності як між окремими особами, так і групами та націями. В інтересах міжнародної злагоди принципово важливо, щоб кожна людина, громада та нація усвідомлювали і поважали багатокультурний характер людського співтовариства. У формуванні толерантності сучасної молоді чільне місце приділяється розвитку демократичного мислення, пошуку нових підходів до виховної діяльності, урахуванню історично-культурних традицій різних регіонів України.

У контексті зазначеного вище науковий і практичний інтерес становить проблема культурологічного підходу у формуванні толерантності майбутніх учителів. Дослідники В. Аніщенко, О. Падалка дають таке визначення поняття: «Культурологічний підхід у дослідженнях проблем педагогічної освіти являє собою сукупність теоретикометодологічних положень й організаційно-педагогічних заходів, спрямованих на забезпечення умов для оволодіння майбутнім вчителем змістом педагогічної культури і розвитку вчителя як її суб'єкта» (Анщенко В., Падалка О., 2013).

Стратегія формування толерантності за допомогою культурологічного підходу полягає в тому, щоб забезпечити особистості всі необхідні умови для їі духовного розвитку, інтелектуально-моральної свободи, вибору поведінки, формування почуття громадянськості, патріотичної й національної самосвідомості, вільної світоглядної позиції, уміння відстоювати свої переконання щодо збереження миру на Землі, гуманного та толерантного ставлення до оточуючих.

Культурологічний підхід має істотне значення для визначення шляхів і тенденцій розвитку толерантної міжкультурної компетенції майбутнього фахівця. Якщо говорити про цей підхід як теоретико-прикладну галузь у царині мовної педагогіки, то він набуває додатково цілу низку соціально-педагогічних функцій. По-перше, культурологічний підхід забезпечує вивчення загальнотеоретичних основ розвитку полікультурної мовної особистості учня в процесі спільного вивчення мов, культур і цивілізацій. По-друге, він концентрує увагу на ціннісно-орієнтаційному змісті культурологічної освіти засобами мов, що вивчаються одночасно і досліджує діапазон впливу соціалізації іншомовного спілкування учнів. По-третє, він дозволяє визначати принципи культурологічної освіти засобами різних мов з урахуванням соціокультурного контексту їх вивчення. По-четверте, культурологічний підхід дозволяє звернутися до проблем відбору культурологічного матеріалу для навчальних цілей, його структурування для різних освітніх контекстів і розробки технології експертної оцінки культурологічного наповнення навчальної літератури.

Якщо розглядати культурологічний підхід у контексті освітньої практики, то він збагачує професійно-педагогічні функції сучасного педагога. Науковиця Г. Гайсина виділяє в структурі професійно-педагогічної діяльності такі функції інформаційну, розвивальну, орієнтаційну, мобілізаційну, конструктивну, комунікативну, організаційну та дослідницьку функції (Гайсина Г., 2002). Ми вважаємо, що саме в цих функціях найбільш наочно проявляються можливості використання культурологічного підходу як інструменту професійної діяльності викладача. Розглянемо зазначені функції в контексті культурологічного підходу.

1. Інформаційна функція. Органічний зв'язок інформаційної функції викладача з культурологічним аналізом проявляється при формуванні культурного кругозору студентів у тих фрагментах навчально-виховного процесу, коли викладач, спираючись на «ціннісно-аналітичний» підхід до культури, повідомляє студентам конкретний матеріал, що характеризує найважливіші досягнення людства в його історичному розвитку. Культурологічний аналіз як засіб пошуку й переробки соціокультурної інформації розширює особистісно інформаційний простір самого викладача, збільшуючи обсяг професійного тезауруса і збагачуючи індивідуальну картину світу.

2. Розвивальна функція. Ця функція пов'язана з розвитком пізнавальних здібностей студентів. Відомо, що навчання набуває розвивального характеру лише при цілеспрямованому управлінні розумовою діяльністю учнів. На основі культурологічного підходу викладач має змогу формувати у студентів здатність вирішувати різні типи навчальнопізнавальних завдань: розпізнавати та класифікувати різні явища і факти культури; виявляти й порівнювати суттєві спільні та відмінні ознаки соціокультурних феноменів; виділяти й описувати моральні та естетичні складники в об'єктах 
культури; здійснювати пошук соціокультурної інформації; виділяти соціокультурні проблеми; будувати оцінювальні шкали тощо. Як бачимо, культурологічний підхід при вирішенні завдань розвивального характеру $є$ специфічним дидактичним засобом, що забезпечує формування у студентів готовності до широкої пошукової діяльності в постійно мінливому соціокультурному середовищі.

3. Орієнтаційна функція. Ця функція сприяє формуванню в студентів системи ціннісних орієнтацій, позитивних відносин і соціально значущих мотивів поведінки й діяльності. У межах цієї функції культурологічний підхід спрямований головним чином на аксіологічну інтерпретацію культури, на багатосторонню оцінку тієї сфери буття людини, яку можна назвати світом цінностей. Крім того, орієнтаційна функція в поєднанні з культурологічним підходом забезпечує освоєння інноваційних ідей і уявлень про фундаментальні напрями духовного життя суспільства, критеріїв морального здоров'я людини й загальної інтелектуальної культури особистості з урахуванням сучасних уявлень про змістовне наповнення загальнолюдських цінностей.

4. Мобілізаційна функція. Ця функція пов'язана з виробленням у студентів широкого набору умінь і навичок, що сприяють розвитку в них пізнавальної активності та самостійності. Вона проявляється в професійно-педагогічній діяльності викладача при актуалізації життєвого досвіду учнів і активізації їх інтелектуальних сил при вирішенні навчальних завдань. У зв'язку з цим культурологічний підхід забезпечує інтеграцію засвоєних знань через розкриття істотних зв'язків соціокультурних явищ і процесів, через оволодіння способами й прийомами культурологічного пізнання, які забезпечують застосування соціокультурних знань у життєвих ситуаціях. Завдяки застосуванню культурологічного підходу як засобу реалізації мобілізаційної функції педагога можливе формування таких інтелектуальних умінь, які дозволяють студенту самостійно здійснювати пошук необхідної інформації, поповнювати й перетворювати її залежно від конкретних завдань навчання.

5. Конструктивна функція. У межах проєктно-конструктивної діяльності педагога його власні культурологічні знання і вміння сприяють вирішенню таких дидактичних завдань:

- проводити відбір і систематизацію соціогуманітарного матеріалу відповідно до мети і завдань освітнього процесу та сучасним соціокультурним запитам і тенденціям;

- здійснювати дидактичну переробку різноманітної культурологічної інформації в матеріал навчальної дисципліни з метою посилення його гуманістичної спрямованості;

- виділяти важливі з огляду на культурологічний розвиток учнів дидактичні одиниці: ідеї, принципи, основні поняття, факти, проблеми культурологічного характеру;

- установлювати міждисциплінарні зв'язки з метою формування у студентів цілісного соціогуманітарного знання, основ культурологічного сприйняття соціальних явищ і процесів.

6. Комунікативна функція. Культурологічний підхід, що реалізується в межах комунікативної функції, відтворює найрізноманітніші моделі людського спілкування, закладає основи комунікативної компетенції. Суттве значення в цьому зв'язку набуває культурологічна підготовленість самого педагога, бо вона сприяє адекватному транскультурному спілкуванню. Таке спілкування, поряд зі знанням культури іншого народу, передбачає володіння певними культурологічними вміннями (співвідносити знання про іншомовну культуру зі знаннями своєї культури, поводити себе відповідно до вимог етикету іншого народу, вибирати адекватні способи вирішення комунікативного завдання тощо).

7. Організаторська функція. Організаторська діяльність викладача полягає в послідовній реалізації різноманітних педагогічних проєктів у навчальній і позанавчальній діяльності студентів, у створенні організаційно-педагогічних умов для виявлення їх задатків і розвитку інтересів, індивідуальних здібностей. У межах організаторської діяльності культурологічний підхід сприяє вирішенню таких педагогічних завдань:

- формування певних традицій при організації студентського колективу, у якому закладаються відповідні форми і правила його існування, формується готовність використовувати й інтерпретувати засвоєні в процесі навчання культурні зразки в руслі актуальних потреб розвитку суспільства;

• організація та забезпечення необхідної взаємодії освітнього закладу й соціуму;

- створення психолого-педагогічних умов для оптимізації соціальної адаптації та активного самовизначення студентів в новому соціально-економічному та культурному середовищі;

- організація позааудиторної виховної роботи культурологічного спрямування (історія мистецтв, зарубіжна література, міжкультурна комунікація зі студентами інших країн тощо).

8. Дослідницька функція. Для педагогічної діяльності першорядне значення має «гностичний компонент структури діяльності», тобто здатність знаходити нове оригінальне рішення теоретичних і практичних проблем. Безсумнівну роль у реалізації дослідницької функції відіграють культурологічні знання і вміння педагога, щоб забезпечити вирішення завдань і проблем, що зустрічаються в педагогічній діяльності, зокрема: розробка концепцій і програм розвитку освітньої установи; моделювання якісних сторін соціокультурних явищ, безпосередньо пов'язаних із прийняттям відповідальних педагогічних рішень; аналіз педагогічних систем у соціокультурному контексті, співвіднесення педагогічних процесів і явищ з іншими процесами соціалізації; проведення педагогічних досліджень, спрямованих на вивчення питань,що цікавлять педагога; пошук нової соціокультурної інформації тощо.

Отже, культурологічний підхід особливо проявляється у діяльності викладача, який здійснює навчання майбутніх учителів початкових класів, оскільки в цьому процесі вирішуються проблеми толерантного виховання, 
що передбачає наявність різних культурних і виховних інтересів, взаємодію між людьми з різними традиціями, орієнтацію на діалог культур.

\section{ВИСНОВКИ ТА ПЕРСПЕКТИВИ ПОДАЛЬШИХ ДОСЛІДЖЕНЬ}

Отже, проблема формування толерантності й культурологічного підходу як засобу формування ї̈ у майбутніх фахівців $€$ однією із актуальних проблем сучасного світу. Суспільство серйозно стурбоване негативними проявами політичного та релігійного екстремізму, ксенофобії та етнічної нетерпимості. Усі ці негативні явища сьогодення можна розглядати як наслідок недостатності або відсутності толерантності в окремих людей і соціальних груп. Однак одного відкритого декларування толерантності як загальнолюдської цінності замало. Необхідно, щоб стратегія формування толерантності за допомогою культурологічного підходу залучалася в систему ціннісних орієнтацій кожної особистості, бо культура толерантності - не тільки загальнолюдський принцип спільного мирного співжиття й норма гуманних взаємин, але й активна та реальна сила розвитку суспільства.

Проведене дослідження не вичерпує всіх аспектів окресленої проблеми. Подальшого вивчення і розвитку потребує, зокрема, питання визначення та реалізації педагогічних умов, які сприяють ефективному формуванню толерантності майбутніх фахівців (зокрема, майбутніх учителів початкових класів) на засадах культурологічного підходу.

\section{СПИСОК ВИКОРИСТАНИХ ДЖЕРЕЛ}

Аніщенко В., Падалка О. (2013). Культурологічний підхід у професійній підготовці вчителя. Освіта дорослих: теорія, досвід, перспективи, 6, 103-107.

Гайсина Г. (2002). Культурологический подход в теории и практике педагогического образования: дис. ... докт. пед. наук : спец. 13.00.08 «Теория и методика профессионального образования. М.

Лекторский В. (1997). О толерантности, плюрализме и критицизме. Вопросы философии, 11, $46-54$

Потапчук Т., Клепар М. (2020). Толерантність та педагогіка толерантності: проблеми наукових досліджень. Гірська школа Українських Карпат, 22, 26-30. doi: 10.15330/msuc.2020.22.26-30

\section{REFERENCES}

Anishchenko V., Padalka O. (2013). Culturological approach in teacher training. Adult education: theory, experience, prospects, 6, 103-107.

Haysyna H. (2002). Culturological approach in the theory and practice of pedagogical education: the dissertation on competition of the doctor of pedagogical sciences: a specialty 13.00 .08 «Theory and a vocational training technique. M.

Lektorskyy V. (1997). About tolerance, pluralism and criticism. Questions of philosophy, 11, 46-54.

Potapchuk T., Klepar M. (2020). Tolerance and pedagogy of tolerance: problems of scientific research. Mountain School of Ukrainian Carpaty, 22, 26-30. doi: 10.15330/msuc.2020.22.26-30

Статтю подано до редколегії 13.09 .2020 p.

Рекомендовано до друку 27.09.2020 p. 